\title{
Influence of Calcium chloride and Gibberellic acid levels on the growth, yield and quality of tomato in the agro- climatic conditions of Mardan-Pakistan
}

\author{
Wiqar Muhammad, Muhammad Noman Khan, Muhammad Ilyas*, \\ Majid Hissam, Waqas Khan, Babar Ali, Muhammad Riaz Khan and \\ Muhammad Hilal \\ Department of Horticulture, The University of Agriculture Peshawar, KP-Pakistan \\ *Corresponding author's email: muhammadalyas12322@gmail.com \\ Citation
}

Wiqar Muhammad, Muhammad Noman Khan, Muhammad Ilyas*, Majid Hissam, Waqas Khan, Babar Ali, Muhammad Riaz Khan and Muhammad Hilal. Influence of Calcium chloride and Gibberellic acid levels on the growth, yield and quality of tomato in the agro-climatic conditions of Mardan-Pakistan. Pure and Applied Biology.Vol. 8, Issue 2, pp1191-1205. http://dx.doi.org/10.19045/bspab.2019.80061

\begin{tabular}{llll}
\hline \hline Received: 26/01/2019 & Revised: 01/04/2019 & Accepted: 08/04/2019 & Online First: 18/04/2019 \\
\hline \hline
\end{tabular}

\begin{abstract}
Tomato is an important vegetable commercialized in Pakistan, and the use of Gibberellic acid $\left(\mathrm{GA}_{3}\right)$ to cultivate it in the Peshawar valley may promote the production of high quality tomato. Therefore, A field experiment was conducted at the Agriculture Farm of Abdul Wali Khan University Mardan during summer 2017, to study the influence of calcium chloride and gibberellic acid levels on the growth yield and quality of tomato. (Cv. Ontario). There were four concentrations of calcium chloride i.e0, 3, 6, and9\% and four levels of $\mathrm{GA}_{3}$ i.e, $0,50,75$ and $90 \mathrm{ppm} \mathrm{ha}^{-1}$. The experiment was laid out in randomized complete block design (RCBD) having three replication. Applications of calcium chloride and gibberellic acid levels have significant effect on the growth, yield and quality of tomato. The maximum number of branches plant ${ }^{-1}(8.18)$, number of flower cluster plant ${ }^{-1}(10)$, number of flower plant ${ }^{-1}(45)$, number of fruit cluster plant ${ }^{-1}(6)$, number of fruit plant ${ }^{-1}(27)$, yield plant ${ }^{-1}(2.0 \mathrm{~kg})$, yield $\operatorname{plot}^{-1}(8 \mathrm{~kg})$ yield ha ${ }^{-1}\left(22\right.$ tons), weight of individual fruit $(80.3 \mathrm{~g})$, vitamin $\mathrm{C}$ content $\left(69.63 \mathrm{mg} 100 \mathrm{~g} \mathrm{~g}^{-1}\right)$, fruit firmness $(14 \mathrm{~N})$ and cost benefit ratio (1.8) was observed at $75 \mathrm{ppm}$ of $\mathrm{GA}_{3}$, while the maximum plant height $(88.93 \mathrm{~cm})$ was found at $90 \mathrm{ppm}$ of $\mathrm{GA}_{3}$. In case of calcium chloride the maximum number of branches plant $^{-1}(7.19)$, plant height $(87.58 \mathrm{~cm})$, number of flower cluster plant ${ }^{-1}(10)$, number of flower plant $^{-1}(43)$, number of fruit cluster plant ${ }^{-1}(5)$, number of fruit plant ${ }^{-1}(23)$, yield plant ${ }^{-1}(1.6 \mathrm{~kg})$, yield plot ${ }^{1}(6.8 \mathrm{~kg})$ yield ha ${ }^{-1}(18.8$ tons $)$, weight of individual fruit $(74 \mathrm{~g})$, Vitamin C content $\left(70 \mathrm{mg} 100 \mathrm{~g}^{-1}\right)$ and cost benefit ratio (2.3) was found at $9 \%$ of $\mathrm{CaCl}_{2}$, while the maximum fruit firmness $(14.19 \mathrm{~N})$ and minimum blossom end rot $(4.82 \%)$ was noted at $\%$ of $\mathrm{CaCl}_{2}$. It was concluded that $\mathrm{CaCl}_{2}$ at the rate of $9 \%$ and $\mathrm{GA}_{3}$ at the rate of $75 \mathrm{ppm}$ has significant effect on enhancing growth and quality attributes of tomato. Therefore it is recommended that $\mathrm{CaCl}_{2}$ at the rate of $9 \%$ and $\mathrm{GA}_{3}$ at the rate of $75 \mathrm{ppm}$ should be used for maximum growth, yield and quality of tomato in the agro-climatic conditions of DistrictMardan.
\end{abstract}

Keywords: Calcium chloride; Gibberellic acid; Mardan; Quality; Yield

Introduction

Tomato (Lycopersicon esculentum) belongs to family Solanacea and is locally called as Tamater. It is one of the most important and commonly cultivated vegetable crops in the world. Tomato ranks $3^{\text {rd }}$ position in the world in vegetables and is on the first place as processing crop in 
vegetables tropical America is considered as its origin [1]. However, China, Iran, Egypt, Turkey, India, USA, Brazil, Italy, Indonesia and Mexico are the leading tomato producing parts of the world [2].

The major tomato crop is grown in summer; flowers and fruits during the months of May and July, when the temperature could be as high as $45^{\circ} \mathrm{C}$. It grows well at the temperature ranged $25-30^{\circ} \mathrm{C}$ during the day and $21^{\circ} \mathrm{C}$ at night [3]. High temperature, at the flowering stage, results in poor pollens development, low fruit set and poor fruit yield [4, 5]. High temperature also inactivates Rubisco, the major photosynthetic enzyme that decreases the rate of photosynthesis [3]. The high summer temperature is also accompanied by extended high light intensity, which may aggravate other stresses [6]. In tomato plant, the optimum light duration is about 12 hours [7] and excessive light (17 hours) may cause leaf chlorosis [8].

The agro climate conditions of Pakistan are suitable for the cultivation of tomato, In Pakistan tomato has a great demand throughout the year due to its variety of uses in Pakistani dishes both traditional as well as modern foods.

It is very nutritious vegetable which can be used in salads, soups, ketchup, curry, sauce, juice and chutney etc. Tomato is highly nutritious because it contains calories energy (23), Protein ( $2 \mathrm{~g}$ ), water (94\%), $\mathrm{Mg}$ (7 mg), Ca (1 g), Vitamin "C" (31 mg), Vitamin "A" (1000 IU), Riboflavin (0.03 $\mathrm{mg})$, Thiamin $(0.1 \mathrm{mg})$, Niacin $(0.8$ $\mathrm{mg}) .100 \mathrm{~g}^{-1}$ of edible portion [9].

In Pakistan, the area and production of tomato in the year 2013-14 was 52300 ha${ }^{1}$ with 530,000 tones, respectively. Whereas, the average yield of tomato was about 10 tones $\mathrm{ha}^{-1}$. However, in Khyber Pakhtunkhwa this crop was grown on 12.6 ha and produced 113.2 tons tomatoes. The average yield ha ${ }^{-1}$ in Kpk is 8.98 tons [10]. $\mathrm{GA}_{3}$ are growth promoter and can play a major role to improve plant growth, and development of vegetable crop. $\mathrm{GA}_{3}$ is one of the most important growth stimulating substance which help in cell division, and cell elongation, thus it can improve the plant growth and development of many crop [11]. [12] Reported that gibberellic acid $\left(\mathrm{GA}_{3}\right)$ can promote the fruit growth and development in pollinated ovaries which become dormant because of high temperature. It is also important for the better yield of tomato.

Calcium is an important secondary macro nutrient and can play a role in defense singling [13]. Calcium plays a major role in many physiological activity and plant development of bulbous flower [14] (Pan and Dong 1995). Direct applying of Calcium is the most effective method to increase the Calcium content in fruit [15]. Calcium increase vitamin $\mathrm{C}$ content as well as improves the quality of fruit and vegetable and also retains fruit firmness [16]. Calcium is an important nutrient for the growth development, quality and shelf life of tomato. Calcium application to the soil improves the growth of tomato, while applying as a foliar application during fruit growth period it can improve the quality of fruit [17]. Calcium deficiency can reduce the fruit quality and the disease like Blossom end rot and many other physiological disorders [18]. Calcium can play a major role in the cell membrane and cell wall stabilization [19].

In view of the above findings, it can be concluded that $\mathrm{GA}_{3}$ and Calcium are the important sources for the improvement of yield and quality of fruit. Therefore, an experiment was designed to study the influence of Calcium and Gibberellic acid levels on the growth, yield and quality of tomato in the climatic conditions of Mardan; with the following Objective to investigate the optimum level of Calcium chloride for better growth, yield and quality of tomato.To explore the optimum level of $\mathrm{GA}_{3}$ for growth, yield and quality of tomato.To determine the suitable interaction of Calcium chloride and $\mathrm{GA}_{3}$ for the higher growth and yield of tomato. 


\section{Materials and methods}

An experiment "Influence of Calcium chloride and Gibberellic acid levels on the growth, yield and quality of tomato in the climatic conditions of Mardan" was conducted at the Agriculture farm of Abdul Wali Khan University Mardan. The seedling of tomato was acquired from reliable source and was transplanted in the first week of April, 2017 with $50 \mathrm{~cm}$ plant to plant distance and $60 \mathrm{~cm}$ row to row distance. All the management activities were practiced according to the general recommendations.

Different concentration of Calcium chloride i.e., $0,3,6,9 \%$ and $\mathrm{GA}_{3}$ solution with concentration $0,50,75,90 \mathrm{ppm}$ was prepared and sprayed after 30 days of transplantation.

The experiment was laid out as two factors RCBD experiment.

\section{Study parameters}

The following parameters were studied.

\section{Number of branches plant ${ }^{-1}$}

Number of branches were counted from the selected plants from the ground level to the top of the stem and means value were calculated.

\section{Plant height (cm)}

Plant height was measured from the selected plants from the ground surface to the top of the stem and means value was calculated.

\section{Number of flower clusters plant ${ }^{-1}$}

The numbers of flower clusters were counted from the selected plants and the average numbers of flower clusters produced plant ${ }^{-1}$ were calculated.

\section{Number of flowers plant ${ }^{-1}$}

The total numbers of flower were counted from the selected plants. Each time the recorded clusters were marked with permanent marker and the average number of flower produced plant ${ }^{-1}$ were calculated.

\section{Number of fruit clusters plant ${ }^{-1}$}

The numbers of fruit cluster plant ${ }^{-1}$ were counted from the selected plants and the average number of fruit clusters produced plant $^{-1}$ was recorded.

\section{Number of fruits plant ${ }^{-1}$}

The total numbers of fruit were counted from the selected plants and the average numbers of fruit produced per plant were recorded.

\section{Weight of individual fruit (g)}

The weights of Ten (10) randomly selected fruits were taken in each treatment and mean was calculated.

\section{Fruit yield plant $^{-1}(\mathbf{k g})$}

The weight of fruit plant ${ }^{-1}$ was measured by using weighing balance. It was determined by totalling of fruit yield from each plant during the period from first to final harvest and mean were calculated.

\section{Fruit yield plot ${ }^{-1}(\mathbf{k g})$}

The weights of fruit plot $^{-1}$ were measured by using weighing balance. It was determined by totaling of fruit yield from each plot during the period from first to final harvest and mean were calculated.

Fruit yield hectare ${ }^{-1}$ (tons)

It was measured by the following formula: Fruit yield per hectare (ton) $=$ Fruit yield plot $^{-1} \mathrm{~kg} \mathrm{x} 10000 \mathrm{~m}^{2} /$ Area of plot $\left(\mathrm{m}^{2}\right) \mathrm{x}$ $1000 \mathrm{~kg}$

\section{Vitamin C (mg $\left.100 \mathrm{~g}^{-1}\right)$}

Vitamin $\mathrm{C}$ content of 10 randomly selected fruits was determined by analysing their sample in a lab. The average mean was calculated.

\section{Procedure}

$10 \mathrm{ml}$ of juice was taken from the extracted juice of tomato with the help of pipette. It was then poured into the graduated cylinder and after that the volume was raised to 100 $\mathrm{ml}$ with the help of $0.1 \mathrm{~N}$ oxalic acid solution to make $10 \%$ solution. From that $10 \%$ solution, $10 \mathrm{ml}$ was taken with help of pipette and poured into beaker, then it was titrated against the dye solution (2-6 dichloro phenol indo phenol + baking soda ) from the burette and when the pink colour was attained titration was stopped and the reading was noted, Vitamin $\mathrm{C}$ contents was calculated using the following formula.

Vitamin C contents $\left(\mathrm{mg} 100 \mathrm{ml}^{-1}\right)=F \times T$ $\mathrm{x} 100 / D$ x $S \mathrm{x} 100$

Where $\mathrm{F}=$ factor of standardization $(\mathrm{ml}$ of ascorbic acid used) / ( $\mathrm{ml}$ of dye used) 
$\mathrm{T}=\mathrm{ml}$ of dye used for sample $-\mathrm{ml}$ of dye used for blank

$\mathrm{D}=\mathrm{ml}$ of sample taken for titration

$\mathrm{S}=\mathrm{ml}$ of dilute sample taken for titration

Fruit firmness (N)

The firmness of 10 randomly selected fruit were measure by using penetrometer. The mean was calculated.

Blossom end rot (\%)

The blossom end rot was calculated as follow:

BER $(\%)=$ No of ber fruit / Total No of fruit $\mathrm{x} 100$

\section{Cost benefit ratio}

The benefit cost ratio was calculated as follow:

Cost benefit ratio $=$ Gross return $\mathrm{ha}^{-1} /$ Total cost of production

\section{Statistical analysis of data}

The data was statistically analyzed to determine the statistical significance. The means for all the treatments was calculated and the analysis of variance for all the characters was performed by " $F$ " (variance ratio) test. The significance of the difference among the means was evaluated by Least Significance Difference (LSD) according to [20]Steel and Torrie, (1980) for interpretation of the result at $5 \%$ level of probability.

\section{Results and discussion}

This chapter includes the presentation and discussion of the results obtained from the influence of $\mathrm{Cacl}_{2}$ and $\mathrm{GA}_{3}$ on the growth yield and quality of tomato. The influence of different concentration of $\mathrm{Cacl}_{2}$ and $\mathrm{GA}_{3}$ and their interaction on the growth yield and quality of tomato contributing attributes. Yield and quality have been presented in (Table 1 to 14). The results of each parameter in the experiment have been studied and discussed under below.

\section{Number of Branches plant ${ }^{-1}$}

The mean data regarding number of branches plant ${ }^{-1}$ is shown in (Table 1) shows that the influence of Calcium chloride and Gibberellic acid was significant, while their interaction was found non-significant. The mean data showed that the highest number of branches plant $^{-1}$ (8.18) was observed at $75 \mathrm{ppm}$ of $\mathrm{GA}_{3}$, followed by $(7.277)$ at $\mathrm{G}_{4}(90 \mathrm{ppm})$, while the lowest number of branches plant ${ }^{-}$ ${ }^{1}(5.77)$ was recorded in control.In case of Calcium chloride the maximum number of branches plant ${ }^{-1}$ (8.08) were observed at $\mathrm{C}_{4}$ (9\%), followed by (7.19) at $\mathrm{C}_{3}(6 \%)$, while minimum number of branches plant ${ }^{-1}(5.84)$ were recorded in control.

The increase in number of branches may be due to the fact that $\mathrm{GA}_{3}$ rapidly increases the cell division and cell elongation in meristematic region, this result was supported by[21, 22]. Similar results were found by [23] who reported that $\mathrm{GA}_{3}$ significantly increased the number of branches plant ${ }^{-1}$ as compare to control, [24] also reported the same result.

In case of calcium Increase in number of branches may be due to its key role in cell division, mitosis and carbohydrates metabolism [25]. Same result were shown by [26], who reported that $\mathrm{Ca}$ have a significant effect on the number of branches plant $^{-1}$, he reported that maximum number of branches plant ${ }^{-1}$ (7) were recorded at 15 $\mathrm{Mm} \mathrm{CaCl}_{2}$ as compare to control. [27]also found similar results in Okra.

Table 1. Number of branches plant ${ }^{-1}$ as affected by $\mathrm{GA}_{3}$ and $\mathrm{CaCl}_{2}$ in tomato

\begin{tabular}{|c|c|c|c|c|c|}
\hline $\mathrm{CaCl}_{2}(\%)$ & \multicolumn{4}{|c|}{$\mathbf{G A}_{3} \mathbf{p p m}$} & \multirow{2}{*}{ Mean } \\
\hline & $\mathbf{0}$ & 50 & 75 & 90 & \\
\hline 0 & 3.74 & 5.42 & 7.03 & 7.17 & $5.84 \mathrm{c}$ \\
\hline 3 & 5.60 & 7.50 & 8.12 & 6.48 & $6.93 \mathrm{~b}$ \\
\hline 6 & 6.95 & 6.65 & 8.58 & 6.57 & $7.19 \mathrm{~b}$ \\
\hline 9 & 6.78 & 7.67 & 9.00 & 8.85 & $8.08 \mathrm{a}$ \\
\hline Mean & $5.77 \mathrm{c}$ & $6.81 \mathrm{~b}$ & $8.18 \mathrm{a}$ & $7.27 \mathrm{~b}$ & \\
\hline
\end{tabular}




\section{Plant height (cm)}

The mean data regarding plant height is shown in (Table2) shows that $\mathrm{GA}_{3}, \mathrm{CaCl}_{2}$ and their interaction significantly affected plant height.

The mean value shows that the maximum plant height $(88.39 \mathrm{~cm})$ were recorded at $90 \mathrm{ppm} \mathrm{GA}_{3}$, followed by $(83.53 \mathrm{~cm})$ at $\mathrm{G}_{3}$ (75ppm) level, while the minimum plant height $(80.20 \mathrm{~cm})$ were recorded in control. In case of Calcium chloride the maximum plant height $(87.58 \mathrm{~cm})$ were recorded at $\mathrm{C}_{4}$ $(9 \%)$, followed by $(84.50 \mathrm{~cm})$ at $\mathrm{C}_{3}(6 \%)$, while minimum plant height $(78.38 \mathrm{~cm})$ were observed at control. In case of interaction the maximum plant height $(95.27 \mathrm{~cm})$ were observed at $\mathrm{C}_{4}(9 \%)$ and $\mathrm{G}_{4}$ $(90 \mathrm{ppm})$. Followed by $(93.33 \mathrm{~cm})$ at $\mathrm{G}_{4}$ (90ppm) and $\mathrm{C}_{3}(6 \%)$, while the lowest plant height $(77.37 \mathrm{~cm})$ were observed at $\mathrm{C}_{1} \mathrm{G}_{1}$ (control).

The increase in plant height due to $\mathrm{GA}_{3}$ application may be due to the reason that, $\mathrm{GA}_{3}$ stimulate cell division, cell elongation and cell enlargement and ultimately lead to better plant growth, [28]. Same result was found by [29] they reported that $\mathrm{GA}_{3}$ have positive effect on the plant height during vegetative growth $[22,30]$ also found the same results. Calcium applications significantly affect the plant height by activating enzyme for mitosis cell division and cell elongation and thus increase the plant height [31]. Same result was found by [32] they reported that maximum plant height $(84.10 \mathrm{~cm})$ was observed at $6 \%$ Calcium. [26] Also found the similar results.

Table 2. Plant height $(\mathrm{cm})$ as affected by $\mathrm{GA}_{3}$ and $\mathrm{CaCl}_{2}$ in tomato

\begin{tabular}{|c|c|c|c|c|c|}
\hline $\mathrm{CaCl}_{2}(\%)$ & \multicolumn{4}{|c|}{$\mathbf{G A}_{3}$ ppm } & \\
\hline & $\mathbf{0}$ & 50 & 75 & 90 & Mean \\
\hline 0 & 77.37 & 78.30 & 81.53 & 78.33 & $78.88 \mathrm{c}$ \\
\hline 3 & 79.97 & 80.50 & 81.53 & 93.33 & $83.83 b$ \\
\hline 6 & 84.57 & 83.10 & 81.70 & 88.63 & $84.50 \mathrm{~b}$ \\
\hline 9 & 78.90 & 86.80 & 89.97 & 95.27 & $87.58 \mathrm{a}$ \\
\hline Mean & $80.20 \mathrm{c}$ & $82.18 b c$ & $83.53 b$ & $88.39 a$ & \\
\hline
\end{tabular}

\section{Number of flower cluster plant ${ }^{-1}$}

The mean data regarding number of flower cluster plant ${ }^{-1}$ as affected by $\mathrm{CaCl}_{2}$ and $\mathrm{GA}_{3}$ are given in (Table 3 ) shows that $\mathrm{CaCl}_{2}$ and $\mathrm{GA}_{3}$ significantly affected number of flower cluster plant ${ }^{-1}$ while their interaction was found non-significant. The mean value shows that the maximum number of flower cluster plant $^{-1}(10.21)$ was found at $\mathrm{G}_{3}$ (75ppm), Followed by $(9.03)$ at $\mathrm{G}_{4}$ (90ppm), while the minimum number of flower cluster plant $^{-1}$ (7.25) was found at control. In case of Calcium chloride, the highest number of flower cluster plant ${ }^{-1}$ (10.17) was found at C4 (9\%), followed by (9.05) at $\mathrm{C}_{3}(6 \%)$, which was statistically similar to $\mathrm{C}_{4}(9 \%)$, while the lowest number of flower cluster plant ${ }^{-1}$ (7.64) was observed in control.
The number of flower cluster plant ${ }^{-1}$ mainly depends on number of branches plant ${ }^{-1}$. As the $\mathrm{GA}_{3}$ resulted in maximum number of branches per plant therefore number of flower cluster ${ }^{-1}$ was also increased this result was confirmed by [21]. Same result was found by [22], who reported that $\mathrm{GA}_{3}$ at $70 \mathrm{ppm}$ can significantly increase number of flower cluster plant ${ }^{-1}$ as compare to control. [33] Also found the similar result. Calcium has a vital role in photosynthesis, enzyme activation and carbohydrates metabolism, which will help to produce more flower cluster [34], same result was found by [35] they reported that the Calcium can significantly increase flower cluster, this result was confirmed by [36]. 
Table 3. Number flower cluster plant ${ }^{-1}$ as affected by $\mathrm{GA}_{3}$ and $\mathrm{CaCl}_{2}$ in tomato

\begin{tabular}{|c|c|c|c|c|c|}
\hline \multirow[t]{2}{*}{$\mathrm{CaCl}_{2}(\%)$} & \multicolumn{4}{|c|}{$\mathbf{G A}_{3} \mathbf{p p m}$} & \multirow[b]{2}{*}{ Mean } \\
\hline & $\mathbf{0}$ & 50 & 75 & 90 & \\
\hline 0 & 3.88 & 8.17 & 9.50 & 9.00 & $7.64 c$ \\
\hline 3 & 7.17 & 8.58 & 10.57 & 7.53 & $8.51 b c$ \\
\hline 6 & 8.87 & 8.67 & 9.83 & 8.83 & $9.05 \mathrm{ab}$ \\
\hline 9 & 9.08 & 10.08 & 10.75 & 10.75 & $10.17 \mathrm{a}$ \\
\hline Mean & $7.25 \mathrm{c}$ & $8.88 \mathrm{~b}$ & $10.21 \mathrm{a}$ & $9.03 \mathrm{~b}$ & \\
\hline
\end{tabular}

\section{Number of flower plant ${ }^{-1}$}

The mean data regarding number of flower plant $^{-1}$ is shown in (Table 4) shows $\mathrm{gA}_{3}$ and $\mathrm{CaCl}_{2}$ have significant effect on the number of flower plant ${ }^{-1}$, while their interaction was found non-significant. The mean value shows that the maximum number of flower $\operatorname{plant}^{-1}(45.10)$ was noted at $\mathrm{G}_{3}(75 \mathrm{ppm})$, followed by (41.57) at $\mathrm{G}_{4}(90 \mathrm{ppm})$, while the minimum number of flower plant $^{-}$ ${ }^{1}$ (37.73) was observed in control. In case of Calcium chloride the maximum number of flowers plant ${ }^{-1}(43.57)$ was found at $\mathrm{C}_{4}$ (9\%), Followed by (42.10) at $\mathrm{C}_{3}(6 \%)$. While the minimum number of flower plant $^{-1}(38.75)$ were recorded in control.

Increase in number of flower may be due to the fact that $\mathrm{GA}_{3}$ increase the levels of endogenous Gibberellin and can play an important role in breaking the dormancy [57]. Same result was found by [29] who reported that $\mathrm{GA}_{3}$ have significantly affected on number of flower plant ${ }^{-1}$ they found the maximum number of flower plant $^{-1}$ (24.58) was noted at 50ppm of GA 3 . [37] Swami (2013) also found the same result in strawberry. Calcium play a vital role in chlorophyll component cell wall and membrane integrity enhance pollen germination and growth, and activator of enzyme which help to increase number of flowers $[38,53]$. Same result was found by [35] who stated that Calcium can significantly increase the number of flower as compare to control. [26] Also found the similar result.

Table 4. Number of flower plant ${ }^{-1}$ as affected by $\mathrm{GA}_{3}$ and $\mathrm{CaCl}_{2}$ in tomato

\begin{tabular}{|c|c|c|c|c|c|}
\hline \multirow[t]{2}{*}{$\mathrm{CaCl}_{2}(\%)$} & \multicolumn{4}{|c|}{ GA 3 ppm } & \\
\hline & $\mathbf{0}$ & 50 & 75 & 90 & Mean \\
\hline $\mathbf{0}$ & 31.25 & 36.82 & 44.80 & 42.12 & $38.75 \mathrm{c}$ \\
\hline 3 & 38.77 & 38.48 & 43.42 & 38.67 & $39.83 \mathrm{bc}$ \\
\hline 6 & 40.01 & 42.28 & 44.70 & 41.42 & $42.10 \mathrm{ab}$ \\
\hline 9 & 40.90 & 41.82 & 47.47 & 44.09 & $43.57 \mathrm{a}$ \\
\hline Mean & $37.73 \mathrm{c}$ & $39.85 b c$ & $45.10 \mathrm{a}$ & $41.57 \mathrm{~b}$ & \\
\hline
\end{tabular}

\section{Number of fruit cluster plant ${ }^{-1}$}

In (Table 5) shows the mean value regarding number of fruits cluster plant ${ }^{-1}$ and 4.5a shows $\mathrm{GA}_{3}$ and Calcium chloride significantly affected number of fruit cluster plant $^{-1}$, while their interaction was found non-significant. The mean value shows that the maximum number of fruit cluster per plant (6.27) was observed at $\mathrm{G}_{3}$ (75ppm), Followed by (5.35) at $\mathrm{G}_{4}$ (90ppm), while the minimum number of fruit cluster plant ${ }^{-1}$ (4.87) at control. In case of Calcium chloride the more number of fruit cluster plant ${ }^{-1}(5.91)$ was noted at $\mathrm{C}_{4}$ (9\%), followed by (5.67) at $\mathrm{C}_{4}(6 \%)$ and $\mathrm{C}_{3}$ $(6 \%)$ level. While the less number of fruit cluster plant ${ }^{-1}(4.74)$ was found at $C_{1}$ (control) level.

More number of fruit cluster per plant is due the maximum number of flower cluster. $\mathrm{GA}_{3}$ help to increase number of flower cluster and fruit-set plant ${ }^{-1}[30]$. [12] Also found the similar results i.e., $\mathrm{GA}_{3}$ increased number of fruit cluster, fruit set percentage as compare to control. Calcium reduces the abscission of flowers and fruit which results 
increased number of fruit cluster [39] same result was found by [35] who reported that the Calcium can significantly increase the number of fruit cluster plant ${ }^{-1}$ as compare to control.

Table 5.Number of fruit cluster plant ${ }^{-1}$ as affected by $\mathrm{GA}_{3}$ and $\mathrm{CaCl}_{2}$ in tomato

\begin{tabular}{|c|c|c|c|c|c|}
\hline \multirow{2}{*}{$\mathrm{CaCl}_{2}(\%)$} & \multicolumn{4}{|c|}{$\mathbf{G A}_{3} \mathbf{p p m}$} & \multirow[b]{2}{*}{ Mean } \\
\hline & 0 & 50 & 75 & 90 & \\
\hline 0 & 4.13 & 4.77 & 5.29 & 4.75 & $4.74 \mathrm{c}$ \\
\hline 3 & 4.63 & 5.48 & 6.46 & 4.88 & $5.37 \mathrm{~b}$ \\
\hline 6 & 5.53 & 4.98 & 6.60 & 5.55 & $5.67 \mathrm{ab}$ \\
\hline 9 & 5.17 & 5.50 & 6.74 & 6.23 & $5.91 \mathrm{a}$ \\
\hline Mean & $4.87 \mathrm{c}$ & $5.18 b c$ & $6.27 \mathrm{a}$ & $5.35 \mathrm{~b}$ & \\
\hline
\end{tabular}

\section{Number of fruit plant ${ }^{-1}$}

The mean data regarding number of fruits plant $^{-1}$ is shown in (Table 6) shows that the influence of $\mathrm{GA}_{3}$ and $\mathrm{CaCl}_{2}$ on number of fruit plant $^{-1}$ were significant, while their interaction was found non-significant. The mean value shows that the maximum number of fruit plant ${ }^{-1}(27.13)$ was found at $\mathrm{G}_{3}$ (75ppm), Followed by (21.88) at $\mathrm{G}_{4}$ (90ppm), while the lowest number of fruit plant $^{-1}$ (16.83) was observed at control. In case of $\mathrm{CaCl}_{2}$ the maximum number of fruit $\operatorname{plant}^{-1}(23.76)$ was found at $\mathrm{C}_{4}(9 \%)$, Followed by (21.98) at $\mathrm{C}_{3}(6 \%)$. While the minimum number of fruit plant ${ }^{-1}(19.53)$ was observed at control.
More number of fruit plant ${ }^{-1}$ is due to the maximum number of fruit cluster. $\mathrm{GA}_{3}$ promote the development of pollinated ovaries which become dormant due to high temperature which result increased number of fruit plant $^{-1}[12]$. [40] Reported if the concentration of $\mathrm{GA}_{3}$ increases it will reduce both the number and size of fruit. Same result was found by [22]. [41] Reported that $\mathrm{GA}_{3}$ increased number of fruit/plant as compare to control. Calcium reduce the flower drop and also increase the fruit retention [42], same result was found by [32] they stated that the Calcium have positive effect on number of fruit plant ${ }^{-1}$ as compare to control. [35] Also found the similar result.

Table 6.Number of fruit plant ${ }^{-1}$ as affected by $\mathrm{GA}_{3}$ and $\mathrm{CaCl}_{2}$ in tomato

\begin{tabular}{|c|c|c|c|c|c|}
\hline $\mathbf{C a C l}_{\mathbf{2}} \mathbf{( \% )}$ & \multicolumn{4}{|c|}{$\mathbf{G A}_{\mathbf{3}} \mathbf{p p m}$} & \multirow{2}{*}{ Mean } \\
\hline $\mathbf{0}$ & $\mathbf{0}$ & $\mathbf{5 0}$ & $\mathbf{7 5}$ & $\mathbf{9 0}$ & \\
\hline $\mathbf{3}$ & 14.90 & 20.48 & 24.50 & 18.25 & $19.53 \mathrm{c}$ \\
\hline $\mathbf{6}$ & 16.47 & 19.40 & 27.23 & 20.97 & $21.02 \mathrm{~b}$ \\
\hline $\mathbf{9}$ & 17.17 & 20.10 & 28.50 & 22.17 & $21.98 \mathrm{~b}$ \\
\hline Mean & 18.80 & 21.80 & 28.30 & 26.13 & $23.76 \mathrm{a}$ \\
\hline
\end{tabular}

\section{Weight of individual fruit (g)}

The mean data regarding weight of individual fruit is shown in (Table 7) shows that the influence of $\mathrm{Cacl}_{2}$ and $\mathrm{GA}_{3}$ on weight of individual fruit was significant, while their interaction was found nonsignificant. The mean value shown that the maximum weight of individual fruit (80.3g) was found at $\mathrm{G}_{3}(75 \mathrm{ppm})$, followed by (71.1g) at $\mathrm{G}_{4}(90 \mathrm{ppm})$. While the minimum individual fruit weight (59.3 gm) was observed at control. In case of $\mathrm{CaCl}_{2}$ the maximum individual fruit weight $(74.5 \mathrm{~g})$ was found at $\mathrm{C}_{4}(9 \%)$, followed by $(72.23$ g) at $\mathrm{C}_{3}(6 \%)$. While the minimum individual fruit weight $(63.8 \mathrm{~g})$ was found at control.

The maximum individual fruit weight may be due to the fact that $\mathrm{GA}_{3}$ increase the photosynthetic material and its efficient mobilization in plant giving rise to increased stimulation of fruit growth and 
eventually lead to maximize the fruit weight $[11,43]$. Same result was found by [29] who reported that $\mathrm{GA}_{3}$ can significantly increase the fruit weight as compare to control. Calcium applications significantly maximize the plant by activating enzyme for cell mitosis, carbohydrates metabolism and nutrient uptake increase the fruit weight [31]. Same result was found by [32]. They stated that the Calcium have positive effect on fruit weight. [62] Also reported that Calcium can increase the fruit weight as compare to control.

Table 7.Weight of individual fruit (g) as affected by $\mathrm{GA}_{3}$ and $\mathrm{CaCl}_{2}$ in tomato

\begin{tabular}{|c|c|c|c|c|c|}
\hline \multirow[t]{2}{*}{$\mathrm{CaCl}_{2}(\%)$} & \multicolumn{4}{|c|}{$\mathrm{GA}_{3} \mathbf{p p m}$} & \multirow[b]{2}{*}{ Mean } \\
\hline & 0 & 50 & 75 & 90 & \\
\hline 0 & 58.17 & 62.17 & 70.67 & 64.47 & $63.87 \mathrm{c}$ \\
\hline 3 & 60.30 & 69.00 & 78.00 & 70.00 & $69.33 b$ \\
\hline 6 & 59.47 & $\begin{array}{l}70.77 \\
\end{array}$ & 85.87 & 72.83 & 72.23ab \\
\hline 9 & 59.53 & 74.53 & 86.87 & 77.17 & $74.53 a$ \\
\hline Mean & $59.37 \mathrm{c}$ & $69.12 b$ & $80.35 \mathrm{a}$ & $71.12 \mathrm{~b}$ & \\
\hline
\end{tabular}

\section{Yield plant $^{-1}(\mathbf{k g})$}

The mean data regarding yield plant $^{-1}$ is shown in (Table 8) revealed that $\mathrm{CaCl}_{2}$ and $\mathrm{GA}_{3}$ significantly affected yield plant ${ }^{-1}$, while their interaction was found nonsignificant. The mean data shown that the highest yield plant ${ }^{-1}(2.09 \mathrm{~kg})$ was observed at $\mathrm{G}_{3}(75 \mathrm{ppm})$, followed by $(1.3 \mathrm{~kg})$ at $\mathrm{G}_{4}$ (90ppm). While the minimum yield/plant $(0.99 \mathrm{~kg})$ was noted at control. In case of $\mathrm{CaCl}_{2}$ the maximum yield plant $^{-1}(1.68 \mathrm{~kg})$ was found at $\mathrm{C}_{4}(9 \%)$, Followed by $\quad(1.39$ $\mathrm{kg})$ at $\mathrm{C}_{3}(6 \%)$. While the minimum yield plant $^{-1}(1.18 \mathrm{~kg})$ was observed at control. The maximum yield plant $^{-1}$ is due to increased number of fruit and fruit weight by $\mathrm{GA}_{3} . \mathrm{GA}_{3}$ are growth stimulating substance which help to improve the plant growth and development and also increase the fruit set in tomato [41], same result was found by [52] they reported that the application of $\mathrm{GA}_{3}$ can significantly increase the yield plant $^{-1}$.[54] also reported that $\mathrm{GA}_{3}$ can increase yield plant $^{-1}$ as compare to control. Calcium is important elements for the growth and yield of plant and act as an activator of enzyme[33], yield plant $^{-1}$ depend on nutrient uptake, and fruit weight, calcium increase these parameters and ultimately increases yield plant ${ }^{-1}$ [67] same result was found by $[26,69]$ they reported that Calcium can significantly increase yield plant ${ }^{-1}$ as compare to control.

Table 8.Yield plant ${ }^{-1}(\mathrm{~kg})$ as affected by $\mathrm{GA}_{3}$ and $\mathrm{CaCl}_{2}$ in tomato

\begin{tabular}{|c|c|c|c|c|c|}
\hline $\mathbf{C a C l}_{\mathbf{2}} \mathbf{( \% )}$ & $\mathbf{6}$ & $\mathbf{6}$ & \multirow{2}{*}{ Gean } \\
\hline $\mathbf{0}$ & $\mathbf{0}$ & $\mathbf{5 0}$ & $\mathbf{7 5}$ & $\mathbf{9 0}$ & $1.18 \mathrm{c}$ \\
\hline $\mathbf{3}$ & 0.89 & 0.90 & 2.02 & 0.93 & $1.36 \mathrm{~b}$ \\
\hline $\mathbf{6}$ & 0.81 & 1.21 & 2.07 & 1.36 & $1.39 \mathrm{~b}$ \\
\hline $\mathbf{9}$ & 0.97 & 1.25 & 2.11 & 1.23 & $1.68 \mathrm{a}$ \\
\hline Mean & 1.29 & 1.55 & 2.14 & 1.73 & \\
\hline
\end{tabular}

Yield plot $^{-1}(\mathrm{~kg})$

The data regarding yield plot $^{-1}$ is shown in (Table 9) showed that the influence of $\mathrm{GA}_{3}$ and $\mathrm{CaCl}_{2}$ on yield plot $^{-1}$ was significant, while their interactive effect was found non-significant. The mean value shows that the more yield plot $^{-1}(8.01 \mathrm{~kg})$ was found at $\mathrm{G}_{3}(75 \mathrm{ppm})$, followed by $(5.62 \mathrm{~kg})$ at $\mathrm{G}_{4}$ (90ppm). While the minimum yield plot $^{-}$ ${ }^{1}(3.95 \mathrm{~kg})$ was observed at control. In case of $\mathrm{CaCl}_{2}$ the highest yield $\mathrm{plot}^{-1}(6.88 \mathrm{~kg})$ was observed at $\mathrm{C}_{4}(9 \%)$, followed by 
$(5.94 \mathrm{~kg})$ at $\mathrm{C}_{3}(6 \%)$ level. While the minimum yield $\operatorname{plot}^{-1}(4.16 \mathrm{~kg})$ was found at control.

$\mathrm{GA}_{3}$ are growth motivating substance which improve the plant growth and development and also increase the fruit set in tomato as well as improve yield weight plant $^{-1}$ which ultimately increases yield plot $^{-1}$, [41]. Same result was found by [54] they stated that $\mathrm{GA}_{3}$ have a significant impact on yield/plant as compare to control. [56] Also found the similar result in mandarin. Increase in yield plot $^{-1}$ due to calcium application might be due to the fact that Calcium not only increase number of fruits but it also reduce fruit drop and increase fruit retention [42], same result was found by [35] they examined that $\mathrm{Ca}$ can increase the yield plant ${ }^{-1}$ as compare to control This result was supported by $[6,48]$.

Table 9.Yield plot ${ }^{-1}(\mathrm{~kg})$ as affected by $\mathrm{GA}_{3}$ and $\mathrm{CaCl}_{2}$ in tomato

\begin{tabular}{|c|c|c|c|c|c|}
\hline \multirow[t]{2}{*}{$\mathrm{CaCl}_{2}(\%)$} & \multicolumn{4}{|c|}{ GA $_{3}$ ppm } & \multirow{2}{*}{ Mean } \\
\hline & $\mathbf{0}$ & 50 & 75 & 90 & \\
\hline ( & 1.83 & 3.22 & 7.10 & 4.50 & $4.16 \mathrm{c}$ \\
\hline 3 & 3.70 & 4.52 & 8.03 & 5.70 & $5.49 \mathrm{~b}$ \\
\hline 6 & 5.23 & 5.17 & 8.13 & 5.23 & $5.94 \mathrm{~b}$ \\
\hline 9 & 5.03 & 6.67 & 8.77 & 7.04 & $6.88 \mathrm{a}$ \\
\hline Mean & $3.95 \mathrm{~d}$ & $4.89 \mathrm{bc}$ & $8.01 \mathrm{a}$ & $5.62 \mathrm{~b}$ & \\
\hline
\end{tabular}

\section{Yield hac hens) $^{-1}$}

The data regarding yield $\mathrm{ha}^{-1}$ was affected by $\mathrm{CaCl}_{2}$ and $\mathrm{GA}_{3}$ is given in (Table 10) showed that the effect of $\mathrm{CaCl}_{2}$ and $\mathrm{GA}_{3}$ was significant, while their interaction effect were found non-significant. The mean value showed that the highest yield $\mathrm{ha}^{-1}$ (22 tons) was found at $\mathrm{G}_{3}$ (75ppm) followed by (16.36 tons) at $\mathrm{G}_{4}$ (90ppm). While the lowest yield ha ${ }^{1}$ (10.5 tons) was observed at $\mathrm{G}_{1}$ control level. In case of $\mathrm{CaCl}_{2}$ the maximum yield $\mathrm{ha}^{-1}$ (18.83 tons) was obtained at $\mathrm{C}_{4}(9 \%)$, followed by (16.97 tons) at $\mathrm{C}_{3}(6 \%)$ level. While the minimum yield ha ${ }^{-1}$ (11.tons) was found at control level.
$\mathrm{GA}_{3}$ increase yield ha ${ }^{-1}$ which may be due to formation of more metabolites resulting in increased flowering, fruit set, fruit weight, and number of fruit [55] $\mathrm{GA}_{3}$ are phytohormone which help to increase these parameters and reduce the fruit drop [50]. Same result was found by [79] they reported that $\mathrm{GA}_{3}$ can significantly increase yield $\mathrm{ha}^{-1}$ as compare to control.[80]also found the similar result. Calcium acts as an activator of enzymes and also important in the process of photosynthesis which increases the production. Same result was found by $[32,35]$ who stated that Calcium increased yield ha- ${ }^{-1}$ as compare to control.

Table 10.Yield ha ${ }^{-1}$ (tons) as affected by $\mathrm{GA}_{3}$ and $\mathrm{CaCl}_{2}$ in tomato

\begin{tabular}{|c|c|c|c|c|c|}
\hline \multirow[t]{2}{*}{$\mathrm{CaCl}_{2}(\%)$} & \multicolumn{4}{|c|}{$\mathbf{G A}_{3} \mathbf{~ p p m}$} & \multirow{2}{*}{ Mean } \\
\hline & $\mathbf{0}$ & 50 & 75 & 90 & \\
\hline 0 & 6.43 & 10.80 & 14.87 & 12.17 & $11.07 \mathrm{c}$ \\
\hline 3 & 11.50 & 10.83 & 22.77 & 18.17 & $15.82 \mathrm{~b}$ \\
\hline 6 & 11.83 & 15.23 & 24.50 & 16.30 & $16.97 \mathrm{~b}$ \\
\hline 9 & 12.40 & 18.13 & 25.90 & 18.80 & $18.83 a$ \\
\hline Mean & $10.56 \mathrm{~d}$ & $13.75 \mathrm{c}$ & $22.01 \mathrm{a}$ & $16.36 \mathrm{~b}$ & \\
\hline
\end{tabular}

Vitamin $C$ content $\left(\mathrm{mg} 100 \mathrm{~g}^{-1}\right)$

The data regarding vitamin $\mathrm{C}$ content is shown in (Table 11). The effect of Calcium chloride and Gibberellic acid was significant, while their interactive effect was found non-significant.

The mean value showed that the highest vitamin $C$ content (69.63 mg $100 \mathrm{~g}^{-1}$ ) was observed at $\mathrm{G}_{3}(75 \mathrm{ppm})$, Followed by 
(65.48mg $\left.100 \mathrm{~g}^{-1}\right)$ at $\mathrm{G}_{4}(90 \mathrm{ppm})$. While the

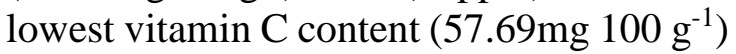
was observed at control. In case of $\mathrm{CaCl}_{2}$ the maximum Vitamin $\mathrm{C}$ content $(70.15 \mathrm{mg}$ $\left.100 \mathrm{~g}^{-1}\right)$ was found at $\mathrm{C}_{4}(9 \%)$, followed by (63.37 $\left.\mathrm{mg} 100 \mathrm{~g}^{-1}\right)$ at $\mathrm{C}_{3}(6 \%)$, while the lowest Vitamin $C$ content $\left(59.53{\mathrm{mg} 100 \mathrm{~g}^{-}}^{-}\right.$ $\left.{ }^{1}\right)$ was found at control. The increase in vitamin $\mathrm{C}$ content may be due to the fact that $\mathrm{GA}_{3}$ increase the mobilization of nutrient, carbohydrates and photosynthetic material which improve the fruit quality
$[11,43]$. [51] Found the similar result in strawberry. Who reported that $\mathrm{GA}_{3}$ at 90 ppm increased Vitamin $\mathrm{C}$ content as compare to control. [49] Also found the similar result in apple. Calcium can increase the Calcium content in fruit [15] increase vitamin $\mathrm{C}$ content as well as improves the quality of fruits [16], same result was found by [26] who reported that $\mathrm{Ca}$ at $10 \mathrm{mM}$ can increased vitamin $\mathrm{C}$ content as compare to control. [35] Also found the similar results.

Table 11. Vitamin $\mathrm{C}$ content $\left(\mathrm{mg}^{100 \mathrm{~g}^{-1}}\right)$ as affected by $\mathrm{GA}_{3}$ and $\mathrm{CaCl}_{2}$ in Tomato

\begin{tabular}{|c|c|c|c|c|c|}
\hline $\mathbf{C a C l}_{\mathbf{2}}(\mathbf{\%})$ & \multicolumn{4}{|c|}{$\mathbf{G A}_{\mathbf{3}} \mathbf{p p m}$} & \multirow{2}{*}{ Mean } \\
\hline $\mathbf{0}$ & $\mathbf{0}$ & $\mathbf{5 0}$ & $\mathbf{7 5}$ & $\mathbf{9 0}$ & \\
\hline $\mathbf{3}$ & 50.57 & 57.00 & 64.95 & 65.58 & $59.53 \mathrm{c}$ \\
\hline $\mathbf{6}$ & 57.23 & 63.37 & 67.67 & 63.83 & $63.03 \mathrm{bc}$ \\
\hline $\mathbf{9}$ & 54.36 & 63.59 & 68.66 & 66.87 & $63.37 \mathrm{~b}$ \\
\hline Mean & 68.58 & 69.13 & 77.23 & 65.65 & $70.15 \mathrm{a}$ \\
\hline
\end{tabular}

\section{Fruit firmness (N)}

Fruit firmness is affected by different levels of $\mathrm{CaCl}_{2}$ and $\mathrm{GA}_{3}$, (Table 12) shown the mean value shows that the effects of $\mathrm{CaCl}_{2}$ and $\mathrm{GA}_{3}$ were significant, while their interaction was found non-significant. The mean value shows that the maximum fruit firmness $(14.01 \mathrm{~N})$ was found at $\mathrm{G}_{3}(75$ ppm), followed by $(11.97 \mathrm{~N})$ at $\mathrm{G}_{4}(90$ ppm), while the minimum fruit firmness $(9.87 \mathrm{~N})$ was observed at untreated control level.In case of $\mathrm{CaCl}_{2}$ the maximum fruit firmness $(14.19 \mathrm{~N})$ was observed at $\mathrm{C}_{3}$ (6\%), Followed by $(12.86 \mathrm{~N})$ at $\mathrm{C}_{4}(9 \%)$.
While the minimum fruit firmness $(9.40 \mathrm{~N})$ was observed at control.

$\mathrm{GA}_{3}$ significantly increase the fruit firmness as compare to control, same result was found by [26] who reported that $\mathrm{GA}_{3}$ increase the fruit firmness as compare to control. [44] Also reported that $\mathrm{GA}_{3}$ increase the fruit size and firmness of cherry fruit. Calcium plays a major role in the cell membrane and cell wall stabilization [19], Calcium improve the quality of fruit and also retain fruit firmness [16], same result was found by [26] who reported that Calcium at $10 \mathrm{mM}$ increase fruit firmness as compare to control.

Table 12.Fruit firmness (N) as affected by $\mathrm{GA}_{3}$ and $\mathrm{CaCl}_{2}$ in tomato

\begin{tabular}{|c|c|c|c|c|c|}
\hline \multirow{2}{*}{$\mathbf{C a C l}_{\mathbf{2}}(\boldsymbol{\%})$} & \multicolumn{4}{|c|}{$\mathbf{G A}_{\mathbf{3}} \mathbf{p p m}$} & \multirow{2}{*}{ Mean } \\
\hline & $\mathbf{0}$ & $\mathbf{5 0}$ & $\mathbf{7 5}$ & $\mathbf{9 0}$ & \\
\hline $\mathbf{0}$ & 7.57 & 9.25 & 12.40 & 8.37 & $9.40 \mathrm{~d}$ \\
\hline $\mathbf{3}$ & 8.83 & 11.23 & 13.20 & 11.27 & $11.13 \mathrm{c}$ \\
\hline $\mathbf{6}$ & 12.50 & 12.93 & 15.55 & 15.77 & $14.19 \mathrm{a}$ \\
\hline $\mathbf{9}$ & 10.57 & 13.27 & 15.13 & 12.47 & $12.86 \mathrm{~b}$ \\
\hline Mean & $9.87 \mathrm{c}$ & $11.67 \mathrm{~b}$ & $14.01 \mathrm{a}$ & $11.97 \mathrm{~b}$ & \\
\hline
\end{tabular}

\section{Blossom-end-rot (\%)}

The data regarding Blossom end rot is given in (Table 13) showed that the influence of
$\mathrm{CaCl}_{2}$ was significant, while the effect of $\mathrm{GA}_{3}$ as well as their interaction was found non-significant.The mean value showed 
that the maximum blossom end rot fruit $(11.68 \%)$ was observed at control. Followed by $(10.68 \%)$ at $\mathrm{C}_{2}(3 \%)$ which was statistically similar to $\mathrm{C}_{1}$ (control) While the minimum blossom end rot fruit $(4.8 \%)$ was found at $\mathrm{C}_{3}(6 \%)$.

Calcium can play a significant role in the stabilization of membrane system and the formation of Calcium-pectates which increase the rigidity of the cell wall and middle portion of the fruit $[45,46]$. Calcium inhibit the degradation of the middle portion and cell wall [47]. And also play a role in defense singling, and reduce the Blossom end rot [13], same result was found by [38] they reported that Ca reduce the Blossom end rot up to $8 \%$ as compare to control. [26] Also reported that Calcium reduce blossom end-rot up to $4 \%$ as compare to control.

Table 13. Blossom end rot (\%) as affected by $\mathrm{GA}_{3}$ and $\mathrm{CaCl}_{2}$ in tomato

\begin{tabular}{|c|c|c|c|c|c|}
\hline \multirow[t]{2}{*}{$\mathrm{CaCl}_{2}(\%)$} & \multicolumn{4}{|c|}{$\mathbf{G A}_{3} \mathbf{p p m}$} & \multirow{2}{*}{ Mean } \\
\hline & $\mathbf{0}$ & 50 & 75 & 90 & \\
\hline $\mathbf{0}$ & 11.57 & 11.67 & 12.47 & 11.00 & $11.68 \mathrm{a}$ \\
\hline 3 & 8.97 & 9.87 & 10.67 & 13.20 & $10.68 \mathrm{a}$ \\
\hline 6 & 5.13 & 4.97 & 4.57 & 4.60 & $4.82 \mathrm{c}$ \\
\hline 9 & 6.00 & 5.50 & 7.90 & 6.93 & $6.58 \mathrm{~b}$ \\
\hline Mean & 7.92 & 8.00 & 8.90 & 8.93 & \\
\hline
\end{tabular}

\section{Economic analysis}

Input cost for land preparation, seed cost, fertilizer and manure cost and man power required for all the operations from transplanting of seedling to harvesting of tomato were recorded for unit plot and converted into cost per hectare. Prices of tomato were considered in market rate basis. The economic analysis was carried outto find the gross and net return and the benefit cost ratio in the current research work and presented under following headings.

\section{Gross return}

$\mathrm{CaCl}_{2}$ showed different gross return under the trial. The maximum gross return (RS $\left.187900 \mathrm{ha}^{-1}\right)$ was obtained from $\mathrm{C}_{4}(9 \%)$, and the minimum gross return (RS 11000 $\left.\mathrm{ha}^{-1}\right)$ was calculated from $\mathrm{C}_{1}(0 \% \mathrm{Ca})$ in case of $\mathrm{GA}_{3}$ the maximum gross return (R.s $220000 \mathrm{ha}^{-1}$ ) was obtained from $\mathrm{G}_{3}$ (75ppm), while the minimum Gross return (RS $105000 \mathrm{ha}^{-1}$ ) at control level.

\section{Net return}

In case of net return, $\mathrm{CaCl}_{2}$ showed different results. The highest net return $\left(\mathrm{RS} 107300 \mathrm{ha}^{-1}\right.$ ) were obtained from $\mathrm{C}_{4}$ (9\%), while the lowest net return (RS 45500 /ha) was obtained from $\mathrm{C} 1$ (control). $\mathrm{GA}_{3}$ showed the highest net return (RS 100000 $\mathrm{ha}^{-1}$ ) were obtained from $\mathrm{G}_{3}(75 \mathrm{ppm})$ level, while the lowest net return (RS $31000 \mathrm{ha}^{-1}$ ) was obtained from control level.

\section{Cost benefit ratio (CBR)}

Highest cost benefit ratio (2.3) was obtained from $\mathrm{C}_{4}(9 \%)$ and the lowest cost benefit ratio (1.8) was obtained from $\mathrm{C}_{1}$ (control). In case of $\mathrm{GA}_{3}$ the highest cost benefit ratio (1.8) was obtained from $\mathrm{G}_{3}$ (75ppm), whereas the lowest (1.2) was found at $\mathrm{G}_{4}(90 \mathrm{ppm})$. From the economic point of view, it is apparent that $\mathrm{CaCl}_{2}$ at $(9 \%)$ and $\mathrm{GA}_{3}$ (75ppm) was the most profitable than rest of the treatments under the study (Table 14). 
Table 14. Cost and return of tomato cultivation as influenced by $\mathrm{GA}_{3}$ and $\mathrm{CaCl}_{2}$

\begin{tabular}{|c|c|c|c|c|c|}
\hline Treatments & $\begin{array}{c}\text { Cost of } \\
\text { production } \text { ha }^{-1}\end{array}$ & $\begin{array}{c}\text { Yield of } \\
\text { tomato (t/ha) }\end{array}$ & $\begin{array}{c}\text { Gross return } \\
\text { (Rs/ha) }\end{array}$ & $\begin{array}{c}\text { Net return } \\
\text { (Rs./ha }\end{array}$ & $\begin{array}{c}\text { Benefit } \\
\text { cost ratio }\end{array}$ \\
\hline C1(Control) & $\mathbf{6 4 5 0 0}$ & $\mathbf{1 1}$ & 110000 & 45500 & 1.8 \\
\hline C2 & $\mathbf{6 9 9 0 0}$ & $\mathbf{1 5 . 8 2}$ & 158200 & 88300 & 2.2 \\
\hline C3 & $\mathbf{7 5 3 0 0}$ & $\mathbf{1 6 . 9}$ & 169000 & 93700 & 2.2 \\
\hline C4 & $\mathbf{8 0 7 0 0}$ & $\mathbf{1 8 . 8}$ & 187900 & 107300 & 2.3 \\
\hline G1(CONTROL) & $\mathbf{6 4 5 0 0}$ & $\mathbf{1 0 . 5}$ & 105000 & 40500 & 1.6 \\
\hline G2 & $\mathbf{1 0 2 0 0 0}$ & $\mathbf{1 3 . 7 5}$ & 137500 & 35500 & 1.3 \\
\hline G3 & $\mathbf{1 2 0 0 0 0}$ & $\mathbf{2 2}$ & 220000 & 100000 & 1.8 \\
\hline G4 & $\mathbf{1 3 2 0 0 0}$ & $\mathbf{1 6 . 3 6}$ & 163000 & 31000 & 1.2 \\
\hline
\end{tabular}

Cost of tomato@Rs.10000/ton

1 gm of $\mathrm{GA}_{3} @$ Rs.3000/gm

\section{Conclusion}

The overall results obtained from the study facilitated to draw the following conclusions; $\mathrm{GA}_{3}$ at a rate $75 \mathrm{ppm}$ was produced the maximum number of branches plant $^{-1}$, number of flower cluster plant ${ }^{-1}$, number of flower plant ${ }^{-1}$, number of fruit cluster plant ${ }^{-1}$ number of fruit plant $^{-1}$, weight of individual fruit, yield plant ${ }^{-1}$, yield plot $^{-1}$, yield $\mathrm{ha}^{-1}$, vitamin $\mathrm{C}$ content, and also increase cost benefit ratio. $\mathrm{CaCl}_{2}$ at rate of $9 \%$ was found best as it increase the number of branches, plant height, number of flower cluster plant $^{-1}$, number of flower plant ${ }^{-1}$, number of fruit cluster plant ${ }^{-1}$, number of fruit plant $^{-1}$, weight of individual fruit, yield plant $^{-1}$, yield plot $^{-1}$, yield ha ${ }^{-1}$, Vitamin C content, as well as cost benefit ratio, whereas $6 \%$ of $\mathrm{CaCl}_{2}$ was consider best for increasing the fruit firmness and reduce blossom end rot. Therefore it is recommended that $\mathrm{GA}_{3}$ at $75 \mathrm{ppm}$ and $\mathrm{CaCl}_{2}$ $9 \%$ was most effective for the better growth yield and quality of tomato.

\section{Authors' contributions}

Conceived and designed the experiments: MN Khan\& $M$ Ilyas, Performed the experiments: W Muhammad, Analyzed the data: W Muhammad, Contributed materials/ analysis/ tools: M Hissam, W Khan, B Ali\& M Hilal, Wrote the paper: M Ilyas.

\section{References}

1. Salunkhe DK, Desai BB \& Bhat NR (1987). Vegetables and flower seed production. 1st Edn. Agricola Publishing Academy, New Delhi, India, pp 118-119.
2. FAO (2002). FAO Production Year Book. Food and Agricultural Organization of the United Nations, Rome 00100, Italy.

3. Camejo D, Rodriguez P, Morales M A, Amico JMD, Torrecillas A \&. Alarco JJ (2005). High temperature effects on photosynthetic activity of two tomato cultivars with different heat susceptibility. J Plant Physiol 162: 281-289.

4. Sato S, Peet MM, Thomas JF (2002). Determining critical pre and post a thesis periods and physiological processes in Lycopersicon esculentum Mill. Exposed to moderately elevated temperatures. $J$ Exp Bot 53: 1187-1195.

5. Pressman E, Peet, MM \& Pharr DM (2002). The effect of heat stress on tomato pollen characteristics is associated with changes in carbohydrate concentration in the developing anthers. Ann. Bot. 90: 631-636. Proceedings $47^{\text {th }}$ Croatian and $7^{\text {th }}$ International Symposium on Agriculture. Opatija, Croatia, pp 419423.

6. Lichtenthaler HK, Babani F Langsdorf G \& Bushcmann C (2001). Measurement of differences in red chlorophyll fluorescence and photosynthetic activity between sun and shade leaves by fluorescence imaging. Photosynthetica 38: 521529. 
7. Menard C, Dorais M, Hovi $\mathrm{T} \&$ Gosselin A (2006). Developmental and physiological responses of tomato and cucumber to additional blue light. Acta Hortic 711: 291-296.

8. Dorais M (2003). The use of supplemental lighting for vegetable crop production: Light intensity, crop response, nutrition, crop management, cultural practices. Canadian Greenhouse Conference October 9.

9. Rashid M M (1983). Sabjeer Chash, 1st Edn, Begum Shahla Rashid Publishers, Joydebpur, Gazipur, 8687.

10. MNFSR. (2011-2012). Government of Pakistan.

11. Pundir JPS \& Yadav PK (2001). Effect of GA3 and NAA on growth, yield and quality of tomato. Current Agric 32 (1\&2); 137-138

12. Gelmesa, D, Abebie B, \& Desalegn L (2012). Regulation of tomato (Lycopersicon esculentum Mill.) fruit setting and earliness by Gibberellic acid and 2, 4-dichlorophenoxy acetic acid application. African $J$ Biotech 11(51): 11200-11206.

13. Soha P, Das N, Deb P \& Suresh CP (2009). Effect of NAA and GA3 on yield and quality of tomato (Lycopersicon esculentum Mill). Environ Eco 27(3): 1048-1050.

14. Pan RC \& Dong YD (1995). Plant physiology (third edition). High education Press, Beijing, China.

15. Conway WS, Sams CE \& Hickey KD (2002). Preand postharvest calcium treatment of apple fruit and first effect on quality. Acta Horti 594: 413-419

16. Bakshi P, Masoodi FA, Chauhan GS $\&$ Shah TA (2005). Role of calcium in post-harvest life of temperate fruits: A review. J of Food Sci and Technol Mysore 42:1-8.

17. Subiah K \& Perumal R (1990). "Effect of Calcium sources concentration, stages and number of spray on physico-chemical properties of tomato fruit". South Indian Horticulture 38(01): 20-27.

18. Adams P \& Ho LC (1993). Effects of environment on the uptake and distribution of Calciumin Tomato and on the incidence of blossom-end rot. Plant and Soil 154: 127- 132.

19. Hirschi KD (2004). The calcium conundrum. Both versatile nutrient and specific signal. Plant Physiol 136: 2438-2442.

20. Steel RGD \& Torrie JH (1980). Procedures of statistics (2nd Edition), McGraw Hill Book Co., Inc. New York, USA

21. Gupta PK \& Gupta AK (2000). Efficacy of plant growth regulators (IAA and NAA) and micronutrient mixture on growth, flowering, fruiting and shelf life of tomato. (Lycopersicon esculentum Mill.). Bioved 11: 25-29.

22. Islam M \& Umer ST (2015). Effect of Gibberellic acid and Boron on the growth and yield of tomato. Thesis, Department of Horticulture, Sher-EBangla Agricultural University Dhaka-1207.

23. Rai N, Yadav DS, Patel KK, Yadav RK, Asat BS \& Chaubey T (2006). Effect of plant growth regulators on growth, yield and quality of tomato, Solanum lycopersicon Mill. grown under mid hill of Meghalaya. Vegetable Sci 33(2): 180-182.

24. Tomar IS \& Ramgiry SR (1997). Effect of growth regulators on yield and a yield attributes in tomato (Lycopersicon esculentum Mill.). Advances Pl Sci 10(2): 29-31.

25. Del Amor FK \& Marcelis LFM. (2003). Regulation concentration. Maximum yield of 20.26 was recorded in of nutrient uptake, water uptake and growth under plants calcium starvation and recovery. J of Horti Sci and Biotechnol 78: 343-349.

26. Kazemi M (2014). Effect of Gibberellic Acid and Potassium Nitrate Spray on Vegetative Growth 
and Reproductive Characteristics of Tomato. J Biol Environ Sci 8(22): 1-9.

27. Kashif SR, Yaseen M, Arshad M \& Abbas M (2007). Evaluation of Calcium chloride as soil amendment to improve nitrogen economy of soil and yield of Okra. Soil and Environ 26(1): 1101-1107

28. Chaudhary BR, Sharma MD, Shakya SM \& Gaut DM (2004). Effect of plant growth regulators on growth, yield and quality of chilli (Capsicum annuum L.). J Inst Agri Anim Sci 27: 65-68.

29. Rahman MS, Haque MA \& Mostafa MG (2015). Effect of $\mathrm{GA}_{3}$ on bio chemical attributes of summer tomato. J of Bio Sci and Agri Res 3(02): 73-78.

30. Naeem $N$, Ishtiaq $M$, Khan $P$, Mohammad N, Khan J \& Jamiher B (2001). Effect of Gibberellic acid on the growth of tomato cv. Roma. Online J of Bio Sci 1(6): 448-450.

31. Jones JB (1999). Tomato plant culture: in the field, as compared to other treatments. Both Caand $\mathrm{Mg}$ are green house and home garden. CRS Press, LLC the essential Elements forthe growth and yield of plants Florida, pp 11-53.

32. Ilyas M, Ayub G, hussain Z, Ahmad M, Bibi B, Rashid A \& luqman (2014). Response of tomato to various level of $\mathrm{Ca}$ and $\mathrm{Mg}$. World Appl Sci J 31 (9): 1560-1564.

33. Haq I, Rab A \& Sajid M (2013). Foliar application of calcium chloride and borax enhance the fruit quality of litchi cultivar. J Anim Plant Sci 23(5): 13851390.

34. Bergmann W (1992). Nutritional disorders of plants. Development, visual and analytical diagnosis. Gustav Fisher Verlag, Jena Germany.

35. Abbasi NA, Zafar L, Khan HA \& Qureshi AA (2013). Effect of NAA and Cacl2 application on nutrient uptake, growth yield and post-harvest performance of tomato fruit. Pak J Bot 45(5): 1581-1587
36. Peyvast G, Olfati JA, Kharazi PR \& Shahmaleki SK (2009). Uptake of calcium nitrate and potassium phosphate from foliar fertilization by tomato. J Hort For 1: 007-13.

37. Swami S R (2013). Effect of growth regulator on the growth yield and quality of Strawberry. Thesis Dr. Yashwantsinghparmer University of horticulture and forestry, Nauni, Solan, 173230.(HP) INDIA.

38. Epstein E (1961). The selective role of calcium in selective cation transport by plant cells, plant phsoilogy 36: 437-444.

39. Rab A \& Haq IU (2012).Foliar application of calcium chloride and borax influences plantgrowth, yield, and quality of tomato (Lycopersicon esculentum Mill.) fruit. Turk J A gric 36: 695-701.

40. Jansen $H$ (1970). The effect of Gibberellic acid and CCC on the yield of tomatoes. Garteribauwissen-Chaf 35:303-306.

41. Akand MH, Mazed HEMK, Pulok MAI, Chowdhury MHN \& Moonmoon JF (2015). Growth and yield of tomato (Lycopersicon esculentum Mill.) as influenced by different level of Gibberellic acid application. Inter $J$ Appl Res 1(3): 71-74.

42. Fletcher RA, Gilley A, Sankhla N \& Davis TD (2000). Triazoles as plant growth regulators and stress protectants. Hortic. Rev 24: 55-138.

43. Bhosle AB, Khorbhade SB, Sanap PB \& Gorad MJ (2002). Effect of plant hormones on growth and yield of summer tomato. (Lycopersicon esculentum Mill.). Orissa J Hort 30(2): 63-65.

44. Choudhury B (1979). Vegetables (6th Revised Edn.).National Book Trust, New Delhi, India, pp 46.

45. Grant GT, Morris ER, Rees DA, Smith PGC \& Thom (1973). Biological interaction between polysaccharide and divalent cation. The egg box model FEBS, LETT 32: 195-198. 
46. Jackman RL \& Stanley DW (1995). "Perspectives in the textural evaluation of plant foods", Trend food. Sci Technol 6: 187-194.

47. Buescher RW \& Hoboson GE (1982). Role of calcium and chelating agents on regulating the degradation of tomato fruit tissue by poly galacturonase. $J$ food, Biochem 6: 147-160.

48. Hao X \& Papadopoulos AP (2003). Effects of calcium and magnesium on growth, fruit yield and quality in a fall greenhouse tomato crop grown on rock wool. Can J Plant Sci 83: 903-912.

49. Khandaker MM, Boyce AN,Osman N, Golam F, Rahman MM \& SofianAzirun M (2013). Fruit Development, Pigmentation and Biochemical Properties of Wax Apple as Affected by Localized Application of GA3 under Field Conditions. Inter $J$ Brazilian Archives of Bio and Tech 56(1): 11-20.

50. Kaushik MP, Shanna JK \& Singh I (1974). Effect of alpha naphthalene acetic acid, gibberellic acid, kinetin and morphactin on yield of tomato. PI Sci 6: 51-53.

51. Kumar R, Sarma N, Jamwal M, Sharma RM. Singh DB \&. Parmar AM (2012). Production and Economic Studies of PBRs Treated Strawberry (Fragaria $\mathrm{x}$
Ananassa Duch.) Cv. Sweet Charli. American-Eurasian J Agric \& Environ Sci 12(12): 1543-154.

52. Lilov D \& Donchev T (1984). Effect of a Bulgarian gibberellin preparation on tomato fruiting. Gradinarska, Lozarska Nauka 21(1): 49-55.

53. Morarad P, Pujos A, Bernadac A \&. Bertoni G (1999). Effect of temporary deficiency on tomato growth and mineral composition. J Plant Nutr 19: 115-127.

54. Sadia A, Tafique T, Rashid M \& Jamal Uddin AFM (2014). Influence of foliar application of Gibberellic on cherry tomato. J Expt Biosci 5(2): 27-30.

55. Singh JP, Randhawa GS \& Jain NL (1960). Response of the strawberry to gibberellic acid. Indian $J$ of Horticulture 17: 21-30

56. Saraswathi T, Rangasamy $\mathrm{P} \&$ Azhakiamanavalan RS (2003). Effect ofpreharvest spray of growth regulators on fruit retention and quality of mandarins (Citrus reticulateBalanco). South Ind Hort 51: 110-112.

57. Wareing PF \& Phillip IDJ (1981). Growth and differentiation in plants, Oxford: Pergamon Press, pp 343. 